\title{
Macrofungi in the Botanical Garden of the University of West Hungary, Sopron
}

\author{
Ádám FOLCZ ${ }^{\mathrm{a}^{*}}$, Zoltán BÖRCSÖK ${ }^{\mathrm{b}}$ \\ ${ }^{a}$ Institute of Silviculture and Forest Protection, Faculty of Forestry, University of West-Hungary, Sopron, Hungary \\ ${ }^{\mathrm{b}}$ Innovation Center, The Simonyi Karoly Faculty of Engineering, Wood Sciences and Applied Arts, \\ University of West-Hungary, Sopron, Hungary
}

\begin{abstract}
Botanical gardens have diverse habitats and floristic conditions. The aim of this study was to examine whether these specific environmental conditions have a positive impact on the appearance of mushrooms. Between 2011 and 2013, mycological observations were performed in the Botanical Garden of the University of West Hungary, Sopron. A total of 171 mushrooms species were identified. Several rare species and two protected species were found. The identification and classification of the species reveal how botanical gardens provide a special habitat for mushrooms. These features of botanical gardens are beneficial for fungal dissemination and preservation.
\end{abstract}

\section{botanical garden/special habitats/fruit-body monitoring/ex situ conservation}

\begin{abstract}
Kivonat-Nagygombák a Nyugat-magyarországi Egyetem Soproni Botanikus Kertjében. A botanikus kertekben, sajátosságaikból adódóan igen változatos term helyi és florisztikai viszonyok vannak. Tanulmányunk célja vizsgálni, hogy ezek a speciális környezeti feltételek milyen kedvez hatással vannak a nagygombák megjelenésére. A 2011-13 években mikológiai megfigyeléseket végeztünk a Nyugat-magyarországi Egyetem soproni botanikus kertjében. Vizsgálataink során összesen 171 nagygomba fajt sikerült kimutatnunk, melyek között számos ritka és két Magyarországon védett faj is el került. A fajok meghatározása és csoportosítása rávilágított arra, hogy milyen speciális él helyet nyújtanak a botanikus kertek a nagygombáknak. A botanikus kert adottságai lehet séget nyújtanak a gombák széleskör megismertetésére és meg rzésre.
\end{abstract}

\section{botanikus kert/speciális él hely/term test monitoring/ex situ meg rzés}

\section{INTRODUCTION}

The history of European botanical gardens dates back to the Middle Ages. They evolved from early herbalist gardens and were already widespread in the 16th century. Their focus shifted to educational and scientific purposes in the 18th century and reached their present form and role in the 18th-19th centuries (Hill 1915). The main objectives of botanical gardens today are to collect, preserve, and exhibit plants native to a given location as well as more colorful or rare non-native species (Brickell 1991, Dongyan - Zuoshuang 2008). These types of gardens have become increasingly important today. Their artificial habitats, diverse flora, and habitat conditions are favorable for mushroom species as well.

\footnotetext{
* Corresponding author: folczadam@gmail.com; H-9400 SOPRON, Bajcsy-Zs. u. 4.
} 
The aim of this study is to illustrate the important role such gardens (e.g. arboretums, botanical gardens, parks) play not only in the preservation of flora, but also in the equally important preservation of mushrooms. We demonstrate this with the example of the Botanical Garden of the University of West Hungary in Sopron.

There are several studies that examine mushrooms occurring in urban environments. Most of these studies focus on the many rare and protected species that appear in urban environments and explore how these urban environments are especially favorable for parasitic and saprotrophic species (Luszczynski 1997, Pál-Fám 2001, Pál-Fám - Boros 2006). The mycological importance of urban parks and gardens emphasizes the differences that exist among artificially created environments and disturbed environments. These green urban areas are an important habitat for mushrooms (Lisiewska - Strakulska 2002, Kasprowicz et al 2011, Skorupski et al 2011, Bujakiewicz - Kujawa 2000). For example, during a five-year study of the People's Garden of Miskolc, a total of 124 species were identified. Of these, only 33 species were mycorrhizal, but several rare and protected species were also found (Kaposvári 2013). Fungi observation in the botanical garden of Soroksár began 40 years ago (Konecsni et al. 1973); since then 274 fungi species have been identified, including a number of rare and protected species (Rimóczi 1993, 1998). A list of 58 species of macromycetes was recorded in the Warsaw Botanical Garden between 1961 and 1963 and is discussed in a paper by Szober (1965). The Central Botanical Garden of Belarus in Minsk recorded 12 species of macromycetes, which is the topic of a paper by Dischuk (2001). In one of his studies, Szczepkowski (2007) identified 79 species of macromycetes in the Dendrological Park of the Warsaw Agricultural University in Warsaw between 1996 and 2005. Arboretums also favor the diversity of the lichen fungi species (Ladd et al 2009). A more preferred topic within the study of fungi in urban environments is the examination of mushrooms nurtured in glasshouses and greenhouses where tropical species can often be found (Pidlich-Aigner et al. 2002, Gubitz 2012, Lukács et al. 2010, 2011). Szczepkowski et al. (2014) reported a total of 206 species that existed in greenhouses in five large European cities. Arboretums also favor the diversity of lichen fungi species (Ladd et al. 2009).

\section{MATERIALS AND METHODS}

\subsection{Description of the study area}

The Botanical Garden of the University of West Hungary is located in Sopron near the northwestern border of Hungary and Austria. Geographically it lies in the eastern foothills of the Sopron hills. From a geobotanical point of view, it is considered a border of the floristic region of the Eastern Alps (Alpicum, subdivision "Ceticum") and the Pannonian basin (Pannonicum, subdivision "Castriferreicum"). Afforestation of the area the Botanical Garden of Sopron occupies today began in 1897; before that, it was home to oak forests, orchards, and kitchen gardens. The development of the Botanical Garden began after 1923 and evolved on 17.2 hectares; the area was primarily used for teaching and practicing forestry. Later, new plantations in plant-geographical clusters were created. Thus, groups of East Asian and North American woody flora evolved (Nemky - Vancsura 1970, Kocsó 1996, 2008). Typically the garden contains a variety of temperate zone plants in its collection and international seed exchanges are largely responsible for their expansion (Kocsó, 1996). Two of the most important missions of the Botanical Garden are to collect a great many and a great variety of taxa, and also to conserve many species (also protected and not threatened) in situ and ex situ. In 2007 the garden contained 2691 woody plan taxa, and 3691 herbaceous taxa and, due to the varied plant cover, there were 57 moss species as well (Kocsó 2008, Szücs 2008). Among the plant taxa were 16 in situ protected species and 135 ex situ protected species (Kocsó 2008). 
The soils of the Botanical Garden were developed on loess, marl and marl-like sediments, and they belong to the reference soil groups of Cambisols and Luvisols. The soil texture is loam, clayey-loam, and the structure is well-formed subangular and angular blocky. The nutrient and water supply statuses of the upper soil horizons are good for weak acidic soil $\mathrm{pH}$. Rain water flows here from the eastern foothills of the Sopron hills providing the area with good water conditions. Due to its geographical location, the garden has a sub-Alpine climate. The average annual rainfall is $690 \mathrm{~mm}$; the 12-hour humidity in July is about 56\%, which is a good climate for hornbeam and oak (Cserpes - Kocsó 1996).

\subsection{Macrofungi investigation}

The mycological observations in the Botanical Garden began in 2004, but our field surveys were completed between 2011 and 2013. The number of surveys varied from six to eight times per year and were weather dependent: there were 1-2 surveys in the spring and 3-4 in the summer and autumn. As the university is located in the garden, informal observations were made frequently.

Table 1.: Date of macrofungi observation

\begin{tabular}{llll}
\hline Years & Spring & Summer & Autumn \\
\hline 2011 & 22.05. & $05.06 . ;$ & $25.09 . ; 04.10 ., 21.10 . ; 07.11$. \\
2012 & 25.05. & 05.06.; 14.06.; 17.07.; & 20.09.; 28.09.; 01-05.10.; \\
& & 24-27.07.; & 17-19.10.; 24.10.; 08.11. \\
2013 & 07.05.; 17.05.; & 05-07.06.; 25.06.; 26.08.; & 05-06.09.; 01-12.09.; 18-19.09.; \\
& & & $01-03.10 . ; 08-10.10 . ; 16-18.10$. \\
\hline
\end{tabular}

Observations of the mushrooms were regularly carried out by exploring the entire Botanical Garden utilizing the garden paths after major rainfalls (Figure 1.). The Botanical Garden has an extremely diverse flora which made it impossible to prepare individual sampling areas.

During the surveys, the number of locations where fruiting bodies of different species were found was recorded (Table 2.). If this occurred in the same location over several years, it is not calculated as a different position. The mushrooms were identified in the field, photo documented and, in some cases, fungarium were also completed. The species were identified by their macroscopical and ecological specifics, as well as their microscopical specifics (cystidium and spore measurements). The spore and cystidia observations were made using a Nikon H600L and a Zeiss Axio Imager light microscope at 600x and 1000x magnification. Images were analyzed with Image Pro Plus 7.0 software. If needed, chemicals reagents were used to identify the fungus (e.g. $10 \% \mathrm{KOH}$, Meltzer-reagent, or by the cystidium observation kongo-red dye stuff was used). The following literature was used during the identification: Kundes - Vesterholt (2012), Bohus et al. (1951), Igmándy (1991), Galli (1996), Krigelsteiner (2000 a, b.), Aronsen (2012), Assoyov - Miksik (2013), Froslev - Stjernegaard (2013), Tulloss - Yang (2014), Bandini (2014).

Nomenclature followed the Mycobank method (Robert et al. 2014). The species found are listed in Table 2 with the name of the taxon and the frequency index $(\mathrm{rA}=$ relative abundance, from 1 to $5 ; 1=$ very rare, $5=$ very common) [how frequently the species was observed during survey time, how abundantly it was found], number of location (Lo). In summary, the Lo value points to a spatial frequency, and the value of rA is the temporal frequency of the appearances. 


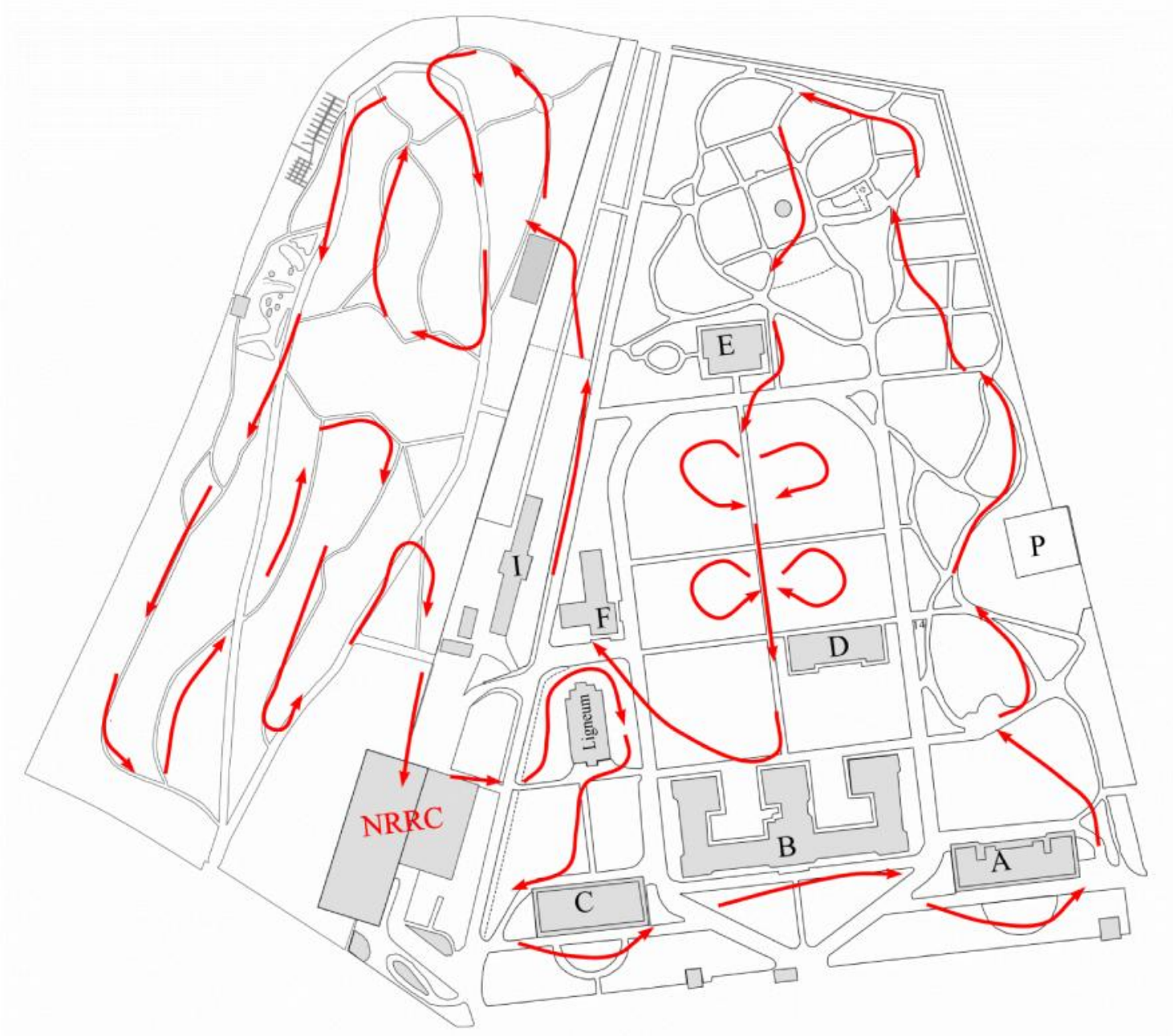

Figure 1: Map of the botanical garden paths used during the observations

The species found were classified on the basis of Arnolds et al. (1995) and our observations (Ls; $\mathrm{m}=$ mycorrhizal, $\mathrm{p}=$ parasite (also necrotorf and biotrof), $\mathrm{sl}=$ saprotrophic lignicole, $\mathrm{st}=$ saprotrophic terricole, $\mathrm{sc}=$ saprotrophic on crop residues). In questionable cases (e.g. Clitopilus prunulus) the work of Rinaldi et al. (2008) was consulted. A conservation assessment was also made based on the works of Rimóczi et al. (1999) and Siller et al. (2005, 2006), taking into account the changes in Hungarian law (Magyar Közlöny 2013). The conservation assessment is in the rightmost column $(\mathrm{P})(0=$ Extinct $1=$ Critically Endangered; 2 =Endangered; 3 = Vulnerable; 4 =Lower Risk; (Rimóczi et al. 1999). The two species highlighted with bold letters are protected by law in Hungary (Magyar Közlöny 2013)

\section{RESULTS, CONCLUSIONS}

Previously Kocsó (2008) mentioned the existence of 75 species in the Botanical Garden, but he does not name them. In the period between 2011 and 2013, 171 mushroom taxa were identified in the Botanical Garden of the University of West Hungary, Sopron (see Table 2 in Appendix).

Categorized by life form, 33\% of the species are mycorrhizal, 5\% are parasitical, $22 \%$ are saprotrophic lignicole, and $40 \%$ are saprotrophic terricole or grow on plant debris. The overall species composition does not differ notably from the composition found in the Sopron hills (Folcz et al. 2013). Among the species are calciphilous and acidophilous species as well. 
When the set of species is compared with data from the Sopron region, we see that the identified species partially overlap in the Dudlesz forest (which has more calcareous substrates) (Frank 1997) and also with the fungi in the Sopron mountains (which is more acidic) (Folcz et al. 2013). In other words, a sorting of blending area exists between the two mushroom worlds which is in line with the growing conditions of the landscape site. Among the species, there are a total of 15 that are yet unpublished for the Sopron area:, Amanita lividopallescens (Secr. ex Boud.) Kühner \& Romagn., Bolbitius titubans (Bull.) Fr., Clitocybe costata Kühner \& Romagn, Galerina laevis Singer, Hygrocybe subglobispora $f$. aurantiorubra Arnolds, Hygrophorus mesotephrus Berk. \& Broome, Hohenbuehelia petaloides (Bull.) Schulzer, Hemimycena cucullata (Pers.) Singer s.l., Lactarius sanguifluus (Paulet) Fr., Leucoagaricus americanus (Peck) Vellinga, Macrotyphula fistulosa (Holmsk.) R.H. Petersen, Melanogaster variegatus (Vittad.) Tul. \& C. Tul., Pluteus ephebeus (Fr.) Gillet, Stropharia coronilla (Bull. ex DC.) Quél., Tephrocybe rancida (Fr.) Donk. Two protected: Agaricus bohusii Bon, Polyporus tuberaster (Jacq. ex Pers.) Fr, ten endangered species, and many rare species occur among the species. Of the species, $42 \%$ (71 species) are on the recommended red list of Hungarian fungi, thus the Botanical Garden plays a significant role in the protection of fungi.

\section{DISCUSSON}

The diversity of vegetation and the special care and treatment inherent to botanical gardens help create exceptional conditions which are highly favorable to the colonization of fungi. The artificial and disturbed soil conditions are favorable for a variety of terrestrial fungi and the diverse flora have a positive effect on mycorrhizal colonization. The garden is cultivated in such a manner that dead wood and wood debris are allowed to accumulate on the forest floor, so the rate of the lignicole mushrooms is similar to that found in natural forests which are also rich in dead wood. Many of the species appear regularly, others appear rarely, which can be traced back to meteorological conditions during the period. Hawksworth (1991) called attention the importance of international protection of fungi. He underlined the importance of both ex-situ and in-situ methods. Moore et al. (2001) recently highlighted the importance of in situ fungi conservation which stresses habitat protection as a key step in fungi protection. The safeguarding of mushrooms in Italy can also be highlighted as an example. One of the cornerstones of this habitat preservation (Venturelli et al. 2011), is the defense of the arbuscular mycorrhizal fungi (Turrini - Giovanetti 2012). In the case of botanical gardens, exsitu mushroom protection is also possible because the gardens are artificial habitats. The rare and protected species that were found show that botanical gardens may be suitable for this task of habitat support if we keep in mind the ex situ (or sometimes the in situ) conservation of the forming and sustaining fungi. Based on our results, botanical gardens are very important habitats for fungi and this provides many opportunities both for science and for active fungi protection (Szober 1965, Pál-Fám et al 2004, Szczepowski 2007). The (ex situ) conservation in such places creates opportunities for mycological research and educational activities and for mycological biodiversity preservation ( Hu - Zhang 2008, Varese et al. 2011).

Acknowledgements: We are grateful to Bálint Dima, László Albert, Gizella Vasas, and Viktor Papp for their help in species determination. We would also like to thank Gábor Kovács and Tamás Cserpes for the verbal information they provided regarding the site types and the study area. 


\section{REFERENCES}

ARNOLDS, E. - KuYPER, T. W. - NoORdEloOS, M. E. (1995) (eds.): Overzicht van de paddestoelen in Nederland. [Overview of mushrooms in the Netherlands] - Nederlandse Mycologische Vereniging, Wijster 871 p. (in Dutch)

Aronsen, A. (2013): The Mycena Page. Arenson, Torod, Norway.

Online: http://home.online.no/ araronse/mycenapage/ mycenapage.html.

Assoyov, B. - MiKsiK, M. (2013): The Bolatales. Assoyov, Sofia, Bulgaria.

Online: http://boletales.com/

BANDINI, D. (2014): Inocybe. Bandini, Wiesenbach, Germany. Online: http://www.inocybe.org/

BRICKELL, C. D. (1991): The educational role of botanic and related gardens. Acta Horticulturae. 299: $59-67$.

Bujakiewicz, A. - KujAwA A. (2000): Macrofungi of manorial park in Turew near Poznan. Acta Mycologica 35 (2): 183-195.

BoHUS, G. - KALMÁR, Z. - UBRIZSY, G. (1951): Magyarország kalaposgombái [Macrofungi of Hungary]. Akadémiai Kiadó, Budapest 511 p. (in Hungarian)

CSERPES, T. - Kocsó, M. (1996): Index Plantarum. Az Erdészeti és Faipari Egyetem Botanikus Kertjének növényjegyzéke [Forestry and Wood Industry University's botanical garden plant list]. Tilia 4: 4-128. (in Hungarian)

DischuK, N. G. (2001): Phytopathology state of coniferous and deciduous trees of the Central Botanical Garden NAS of Belarus. In SALAŠ, P. (ed), Proceedings of 9th International Conference of Horticulture, Lednice, 644-646.

Dongyan, H. -ZuOShuAng, Z. (2008). The role of botanical gardens in horticultural science. Acta Horticulturae 769: 493-496.

FolCZ, Á. - BÖRCSÖK, Z. - DIMA, B. - FrANK, N. (2013): A Soproni-hegység bazídiumos nagygombáinak erdészeti szempontú vizsgálata. [Macrofungi (Basidiomycota) investigations in the Sopron Hills (Western Hungary) from forestry point of view] Erdészettudományi Közlemények 3: 179-194. (in Hungarian)

FRANK, N. (1997): Adatok a Soproni Dudlesz erd nagygombavilágához. [Date on the fungi-world on Sopron Dudlesz-woods]. Mikológiai Közlemények, Clusiana 36 (1): 13-21. (in Hungarian)

Froslev, T. - StJernegaArd, T. (2013): The Phlegmacium website. Froslev T., Copenhagen K, Denmark. Online: http://www.cortinarius.org/

GuBITZ, C. (2012): Mycofloristic studies of the greenhouses in the botanical garden of Bayreuth - part 2. Zeitschrift Für Mykologie 78 (1): 9-52.

GALLI, R. (1996): Le Russule - $1^{\text {a }}$ ed. [The Russula] Edinatura srl, Milano. 480 p. (In Italian)

HAWKSWORTH, D. L. (1991): The fungal dimension of biodiversity: magnitude, significance, and conservation. Mycological Research 95: 641-655.

HILl, A. W. (1915): The History and Functions of Botanic Gardens. Annals of the Missouri Botanical Garden 2(1/2): 185-240.

Hu, D. -ZHANG, Z. (2008): The role of botanical gardens in horticular science. Acta Horticulturae 769: 493-496.

IGMÁNDY, Z. (1991): A magyar erd k taplógombái [Tinders of the Hungarian forests] - Akadémiai kiadó, Budapest. 112 p. (in Hungarian)

KAPOSVÁRI, L. (2013): A miskolci Népkert nagygombavilágának vizsgálata [Mushrooms of the Népkert in Miskolc]. Mikológiai közlemények Clusiana 52 (1-2): 5-20. (in Hungarian)

KASPROWICZ, M. - JAGODZIŃSKI, A. M., - SKORUPSKI, M. - WOJTERSKA, M. - DOBIES, T. KAŁUCKA, I. - SŁAWSKA, M. - WIERZBICKA, A. - ŁABĘDZKI, A. - NOWIŃSKI, M. KAROLEWSKI, P. - OLEKSYN, J. - BANASZCZAK, P. - MAŁEK, S. (2011): The list of plants, fungi and invertebrates of noble fir (Abies procera Rehder) experimental stands in Rogów Arboretum (Poland). Acta Scientiarum Polonica Silvarum Colendarum Ratio et Industria Lignaria 10 (4): 17-27.

Kundsen, H. - Vesterholt, J. (2012) (eds.): Funga Nordica. Vol. 2. Agaricoid, Boletoid and Cyphelloid genera. Nordsvamp, Copenhagen. 1083 p. 
Kocsó, M. (1996): Egyetemi Botanikus Kert - Sopron [Botanical Garden of Sopron]. Tájak Korok Múzeumok Kiskönyvtára 537. szám. TKM Egyesület. Sorozatszerkeszt : Priszter Szaniszló. Budapest. 24 p. (in Hungarian)

Kocsó, M. (2008): Az erdészeti fels oktatás botanikus kertje [Botanical Garden of the foresters higher education]. In: Albert L. (ed.) (2008): Az erdészeti fels oktatás 200 éve. Sopron NyugatMagyarországi Egyetem Erd mérnöki Kar: 145-165 (in Hungarian)

Konecsni, I. - RIMOCZI, I. - TERPÓ, A. (1973): A Soroksári Botanikus Kert gombái és gomba bemutatása. [Macrofungi of Soroksár Botanical Garden] - A Kertészeti Egyetem kiadványai, Növénytani Tanszék és Soroksári Botanikus Kert: 62-76 (in Hungarian)

KRIEGLSTEINER, G. J. (2000a): Die Grosspilze Baden-Württembergs. Band 1. Verlag Eugen Ulmer, Stuttgart, $629 \mathrm{p}$.

KrIEGLSTEINER, G. J. (2000b): Die Grosspilze Baden-Württembergs. Band 2. Verlag Eugen Ulmer, Stuttgart, $620 \mathrm{p}$.

LADD, D. - HARRIS, R. C. - BUCK, W. R. (2009): Lichens and related fungi of Highstead Arboretum, Fairfield County, Connecticut Opuscula Philolichenum, 6: 81-86.

LISIEWSKA, M. - STRAKULSKA, M. (2002): Biodiversity of macrofungi of selected field, afforestation in the agroecological landscape park near Turew (central Wielkopolska), Polish Botanical Journal 47 (2): 167-181.

LUKÁCS, Z. - LOVAS, J. - KÁRNYÁCZKI, C. (2010): Trópusi gombák a budapesti állatkertben. [Tropical fungi in Zoo of Budapest] Mikológiai Közlemények, Clusiana 49 (1-2): 121-127. (in Hungarian)

LUKÁCS, Z. - LOVAS, J. - KÁRNYÁCZKI, C. (2011): Érdekes gombák a f városi állat és növénykertb 1. [Interesting fungi in the Zoo and Botanical Garden of Budapest] Mikológiai Közlemények, Clusiana 50 (1): 49-54. (in Hungarian)

LUSZCZYNSKI, J. (1997): Interesting macromycetes found in the Kielce town (Central Poland). Acta Mycologica 32 (2): 207-228.

MAGYAR KÖZLÖNY (2013): A vidékfejlesztési miniszter 83/2013. (IX. 25.) VM rendelete a védett és a fokozottan védett növény- és állatfajokról, a fokozottan védett barlangok körér 1, valamint az Európai Közösségben természetvédelmi szempontból jelent s növény- és állatfajok közzétételér 1 szóló 13/2001. (V. 9.) KöM rendelet módosításáról [Publication of the Minister for Rural Development about the protected plant and animal species, protected caves.] 156: 67479-67504. (in Hungarian)

Moore, D. - Nauta, M. M. - Evans, S. E. - Rotheroe, M. (eds.) (2001): Fungal conservation: issues and solutions. Cambridge University Press, Cambridge, UK, 262 p.

NEMKY, E. - VANCSURA, R. (1970): Az erdészeti fels oktatás botanikus kertjének története [History of the Botanical Garden of the foresters higher education]. In: Herpay I. (ed.) (1970): Mindnyájan voltunk egyszer az Akadémián... Sopron, 191-1969. Az Erdészeti és Faipari Egyetem Jubileumi évkönyve. Sopron. 261-283 p. (in Hungarian)

PÁL-FÁM, F. (2001): Macrofungi in human habitats. Zeszyty Naukowe 236- Rolnictwo 47: 65-71.

PÁL-FÁM, F. - BENEDEK, L. - RIMÓCZI, I. (2004): Conservation of Macrofungi in Hungary: possibilities and perspectives. Természetvédelmi Közlemények 11: 163-173. (in Hungarian)

PÁL-FÁM, F. - BOROS, V. (2006): Nagygombák vizsgálata Kaposvár városban. [Macrofungi examination in Kaposvár city]. Somogyi Múzeumi Közlemények 17(B): 7-16. (in Hungarian)

Pidlich-Aigner, H. - HAusKnecht, A. - Scheuer, C. (2002): Annotated List of Macromycetes Found in the Greenhouses of the Botanic Garden of the Institute of Botany in Graz (Austria), 1998 - 2001. Fritschiana (Graz) 32: 49-61.

RIMÓCZI, I. (1993): Gombacönológiai és aszpektus vizsgálatok a Pesti-síkság védett területén. [Mycocenological and aspect investigations in the protected area of Pest-plain] - Mikológiai Közlemények, Clusiana 32 (1-2): 43-69. (in Hungarian)

RIMÓCZI, I. (1998): A Soroksári Botanikus Kert nagygomba-világának védend fajai. [To be protected species of mushrooms of the Soroksár Botanical Garden.] Lippay János - Vass Károly Nemzetközi Tudományos Ülésszak 1998. IX. p. 50-51. (in Hungarian) 
RiMócZI, I. - Siller, I. - VASAS, G. - AlBeRT, L. - VeTTER, J. - BRATEK, Z. (1999): Magyarország nagygombáinak javasolt Vörös Listája. [Suggested macrofungi red list of Hungary] Mikológiai Közlemények, Clusiana 38 (1-3): 107-132. (in Hungarian)

RINALDI, A. C. - COMANDinI, O. - KUYPER, T. W. (2008): Ectomycorrhizal fungal diversity separating the Wheat from the chaff. Fungal Diversyti 33: 1-45.

Siller, I. - Dima, B. - Albert, L. - VASAS, G. - Fodor, L. - PÁl-FÁm, F. - BrateK, Z. - ZAGyva I. (2006): Védett nagygombafajok Magyarországon. [Protected macrofungi of Hungary] Mikológiai Közlemények, Clusiana 45 (1-3): 3-158. (in Hungarian)

SILLER, I. - VASAS, G. - PÁL-FÁM, F. - FODOR, L. (2005): The State of protection of macrofungi in Hungary. Acta Microbiologica et Immunologica Hungarica, 52(2): 199-219.

SKORUPSKI, M. - JAGODZIŃSKI, A. M. - KAŁUCKA, I. - KASPROWICZ, M. - WOJTERSKA, M. - DOBIES, T. - SŁAWSKA, M. - WIERZBICKA, A. - ŁABĘDZKI, A. - OlesZYŃSKA-NI NIOWSKA, J. NowiŃSKI, M. - MAŁEK, S. - KAROLEWSKI, P. - OleKSYN, J. - BANASZCZAK, P (2011): Plants, fungi and invertebrates of grand fir [Abies grandis (Douglas ex D. Don) Lindl.] experimental stands in Rogów Arboretum (Poland). Acta Scientarum Polonorum Silvarum Colendarum Ratio et Industria Lignaria 10 (4): 39-49.

SzOBER, J. (1965): Grzyby wy sze Ogrodu Botanicznego Uniwersytetu Warszawskiego. Zobserwacji prowadzonych wlatach 1961-1963. Państwowe Wydawn. Naukowe, Warszawa, 17 p.

SZCZEPKOwSKI, S. A. (2007): Macromycetes in the Dendrological Park of the Warsaw Agricultural University. Acta Mycologica, 42 (2): 179-186.

SZCZEPKOWSKI, S. A. -GIERCZYK, B. -KUJAWA, A. (2014): Greenhouses of botanical gardens as a habitat of alien and native macrofungi: a case study in Poland. Central European Journal of Biology 9 (8): 777-795.

SZÜCS P. (2008): Mohaflorisztikai vizsgálatok a Soproni Botanikus Kertben. [Bryofloristic studies in Botanic Garden in Sopron]. Kitaibella 13(1): 193. (in Hungarian)

Robert, V. - Stegehuis, G. - StalPers, J. (2014): The MycoBank engine and related databases. CBS-KNAW, Utrecht, The Netherlands. Online: http://www.mycobank.org

Tulloss, R. E. - YANG, Z. L. (2014): Studies in the Amanitaceae. Tulloss R. E., Yang Z. L., (eds.) Roosevelt, New Jersey. Online: http://www.amanitaceae.org?home

TURRINI, A. - GIOVANNETTI, M. (2012): Arbuscular mycorrhizal fungi in national parks, nature reserves and protected areas worldwide: a strategic perspective for their in situ conservation. Mycorrhiza, 22 (2): 81-97.

VARese, G.C. - Angelinib, P. - Bencivengab, M. - Buzzinic, P. - DonNinib, D. - Garganod, M. L. Maggie, O. - Pecorarof, L. - Persianie, A. M. - Savinog, E. - Tiginia, V. -Turchettic, B. - VAnNaCcih, G. - Venturellad, G - Zambonellit, A. (2011): Ex situ conservation and exploitation of fungi in Italy. Plant Biosystems, 145 (4): 997-1005.

VenturellaA, G. - Altobellib, E. - Bernicchiac, A. - Di Piazzad, S. - Donninie, D. GARGANOA, M. L. - GORJÒNF, S. P. -GRANITOG, V. M. - LANTIERIH, A. - LUNGHINIG, D. Montemartinid, A. - Padovani, F. - Pavarinod, M. - Pecoraroj, L. - Perinik, C. - Ranal, G. - RIPAM, C. - SALERNIK, E. - SAVINOB, E. - TOMEIN, P. E. - VIZZINIO, A. - ZAMBONELliP, A. - ZotTiD, M. (2011): Fungal biodiversity and in situ conservation in Italy. Plant Biosystems, 145 (4): 950-957. 


\section{APPENDIX}

Table 2. The observed macrofungi species in the botanical garden of the University of West Hungary, Sopron

\begin{tabular}{|c|c|c|c|c|c|}
\hline $\mathrm{Nr}$. & Species & $\mathrm{rA}$ & Lo & Ls & $\mathrm{P}$ \\
\hline \multicolumn{6}{|c|}{ Ascomycota } \\
\hline 1 & Ascocoryne sarcoides (Jacq.) J.W. Groves \& D.E. & 1 & 1 & sl & 3 \\
\hline 3 & Helvella crispa (Scop.) Fr. & 4 & 6 & st & 3 \\
\hline 4 & Helvella elastica Bull. & 1 & 2 & st & 3 \\
\hline 5 & Humaria hemisphaerica (F.H. Wigg.) Fuckel & 1 & 2 & st & 4 \\
\hline 6 & Kretzschmaria deusta (Hoffm.) P.M.D. Martin & 1 & 1 & $\mathrm{p}$ & - \\
\hline 7 & Tarzetta cupularis (L.) Svrček & 1 & 1 & st & 4 \\
\hline 8 & Morchella esculenta (L.) Pers. & 1 & 1 & st & 3 \\
\hline 9 & Peziza varia (Hedw.) Alb. \& Schwein. & 3 & 2 & sl & 4 \\
\hline 10 & Sarcoscypha austriaca (Beck ex Sacc.) Boud. & 2 & 3 & sl & 4 \\
\hline 11 & Xylaria hypoxylon (L.) Grev. & 1 & 2 & sl & - \\
\hline 12 & Xylaria polymorpha (Pers.) Grev & 1 & 3 & sl & - \\
\hline \multicolumn{6}{|c|}{ Bazidiomycota } \\
\hline 13 & Agaricus augustus Fr. & 1 & 2 & st & 2 \\
\hline 14 & Agaricus bitorquis (Quél.) Sacc. & 2 & 1 & st & - \\
\hline 15 & Agaricus bohusii Bon & 1 & 1 & st & 2 \\
\hline 16 & Agaricus campestris L. & 1 & 1 & st & - \\
\hline 17 & Agaricus sylvaticus Schaeff. & 2 & 3 & st & - \\
\hline 18 & Agaricus xanthodermus Genev. & 5 & 10 & st & - \\
\hline 19 & Agrocybe erebia (Fr.) Kühn. & 1 & 1 & st & 2 \\
\hline 20 & Agrocybe praecox (Pers.) Fayod & 2 & 2 & st & - \\
\hline 21 & Amanita battarrae (Boud.) Bon & 1 & 1 & $\mathrm{~m}$ & 3 \\
\hline 22 & Amanita citrina (Schaeff.) Pers. & 1 & 1 & $\mathrm{~m}$ & 3 \\
\hline 23 & Amanita lividopallescens (Secr. ex Boud.) Kühner \& Romagn. & 2 & 1 & $\mathrm{~m}$ & 2 \\
\hline 24 & Amanita muscaria (L.) Lam. & 2 & 2 & $\mathrm{~m}$ & 3 \\
\hline 25 & Amanita phalloides var. phalloides (Vaill. ex Fr.) Link & 3 & 3 & $\mathrm{~m}$ & - \\
\hline 26 & Amanita rubescens Pers. & 1 & 1 & $\mathrm{~m}$ & - \\
\hline 27 & Amanita solitaria (Bull.) Mérat & 2 & 3 & $\mathrm{~m}$ & 2 \\
\hline 28 & Amanita strobiliformis (Paul.:Vitt.) Bertil. & 2 & 4 & $\mathrm{~m}$ & 3 \\
\hline 29 & Armillaria mellea (Vahl.) P. Kumm. & 1 & 1 & $\mathrm{p}$ & - \\
\hline 30 & Armillaria ostoyae (Romagn.) Herink & 1 & 2 & $\mathrm{p}$ & - \\
\hline 31 & Armillaria tabescens (Vahl.) P. Kumm. & 2 & 1 & $\mathrm{p}$ & - \\
\hline 32 & Auricularia auricula-judae (Bull.) Quél. & 1 & 1 & sl & - \\
\hline 33 & Auriscalpium vulgare Gray & 3 & 2 & sl & - \\
\hline 34 & Bolbitius titubans (Bull.) Fr. & 3 & 5 & $\mathrm{sc}$ & 3 \\
\hline 35 & Boletus impolitus Fr. & 1 & 1 & $\mathrm{~m}$ & 4 \\
\hline 36 & Boletus luridus Sowerby & 2 & 3 & $\mathrm{~m}$ & 4 \\
\hline 37 & Boletus radicans Pers. & 3 & 2 & $\mathrm{~m}$ & 3 \\
\hline 38 & Calocybe gambosa (Fr.) Donk & 1 & 1 & st & - \\
\hline 39 & Chlorophyllum olivieri (Barla) Vellinga & 3 & 7 & st & - \\
\hline 40 & Chroogomphus rutilus (Schaeff.) O.K. Mill. & 2 & 2 & $\mathrm{~m}$ & - \\
\hline 41 & Clitocybe costata Kühner \& Romagn & 1 & 1 & st & 3 \\
\hline 42 & Clitocybe gibba (Pers.) P. Kumm. & 2 & 2 & st & 3 \\
\hline
\end{tabular}




\begin{tabular}{|c|c|c|c|c|c|}
\hline Nr. & Species & $\mathrm{rA}$ & Lo & Ls & $\mathrm{P}$ \\
\hline 43 & Clitocybe nebularis (Batsch) P. Kumm. & 1 & 2 & st & 3 \\
\hline 44 & Clitocybe odora (Bull.) P. Kumm. & 1 & 1 & st & 3 \\
\hline 45 & Clitocybe rivulosa (Pers.) P. Kumm. & 1 & 2 & st & 3 \\
\hline 46 & Clitocybula platyphylla (Pers.) Malençon \& Bertault & 1 & 2 & st & - \\
\hline 47 & Clitopilus prunulus (Scop.) P. Kumm. & 2 & 4 & st & - \\
\hline 48 & Coprinellus disseminatus (Pers.) J. E. Lange & 4 & 7 & sl & - \\
\hline 49 & Coprinellus micaceus (Bull.) Vilgalys, Hopple \& Jacq. Johnson & 5 & 6 & sl & - \\
\hline 50 & Coprinopsis atramentaria (Bull.) Redhead, Vilgalys \& Moncalvo & 1 & 1 & sl & - \\
\hline 51 & Coprinus comatus (O. F. Müll.) Pers. & 4 & 5 & st & - \\
\hline 52 & Coprinus leiocephalus P.D. Orton & 1 & 1 & st & - \\
\hline 53 & Coprinus cinereus S.F. Gray & 1 & 1 & $\mathrm{sc}$ & - \\
\hline 54 & Cortinarius infractus Berk. s. $l$. & 1 & 1 & $\mathrm{~m}$ & - \\
\hline 55 & Cortinarius largus Fr. & 1 & 1 & $\mathrm{~m}$ & 3 \\
\hline 56 & Cortinarius subpurpurascens (Batsch) Fr. & 1 & 2 & $\mathrm{~m}$ & 3 \\
\hline 57 & Cortinarius trivialis J. E. Lange $s . l$. & 2 & 1 & $\mathrm{~m}$ & - \\
\hline 58 & Crepidotus mollis (Schaeff.) Staude & 1 & 1 & sl & - \\
\hline 59 & Cyathus olla (Batsch) Pers. & 2 & 3 & sl & - \\
\hline 60 & Cyathus striatus (Huds.) Willd. & 3 & 4 & sl & - \\
\hline 61 & Dacrymyces chrysospermus Berk. \& M.A. Curtis & 1 & 2 & sl & - \\
\hline 62 & Daedalea quercina (L.) Pers. & 1 & 1 & sl & - \\
\hline 63 & Entoloma rhodopolium (Fr.) P. Kumm. & 1 & 1 & $\mathrm{~m}$ & - \\
\hline 64 & Exidia nigricans (With.) P. Roberts & 1 & 2 & sl & - \\
\hline 65 & Flammulina velutipes (Curtis) Singer & 1 & 2 & $\mathrm{p}$ & - \\
\hline 66 & Fomitopsis pinicola (Sw.) P. Karst & 1 & 1 & $\mathrm{p}$ & - \\
\hline 67 & Galerina laevis (Pers.) Singer & 1 & 3 & st & 3 \\
\hline 68 & Geastrum fimbriatum Fr. & 1 & 1 & st & 3 \\
\hline 69 & Geastrum triplex Jungh. & 3 & 5 & st & 3 \\
\hline 70 & Gomphidius glutinosus (Schaeff.) Fr. & 2 & 2 & $\mathrm{~m}$ & - \\
\hline 71 & Gymnopus dryophilus (Bull.) Murrill & 5 & 9 & st & - \\
\hline 72 & Gymnopus fusipes (Bull.) Gray & 1 & 1 & sl & - \\
\hline 73 & Hebeloma crustuliniforme (Bull.) Quél. & 1 & 2 & $\mathrm{~m}$ & - \\
\hline 74 & Hemimycena cucullata (Pers.) Singer $s . l$. & 2 & 3 & st & 2 \\
\hline 75 & Hemipholiota populnea (Pers.) Bon & 1 & 1 & sl & - \\
\hline 76 & Hohenbuehelia petaloides (Bull.) Schulzer & 1 & 1 & st & 3 \\
\hline 77 & Hygrocybe ceracea (Wulf.) P. Kummer. & 1 & 1 & st & 3 \\
\hline 78 & Hygrocybe subglobispora f. aurantiorubra Arnolds & 1 & 1 & st & 2 \\
\hline 79 & Hygrocybe virginea (Wulfen) P.D. Orton \& Watling & 1 & 1 & st & 2 \\
\hline 80 & Hygrophoropsis aurantiaca (Wulfen) Maire & 1 & 2 & st & - \\
\hline 81 & Hygrophorus hypothejus (Fr.:Fr.)Fr. & 1 & 1 & $\mathrm{~m}$ & 3 \\
\hline 82 & Hygrophorus mesotephrus Berk. \& Broome & 1 & 1 & $\mathrm{~m}$ & 3 \\
\hline 83 & Hypholoma fasciculare (Huds.) P. Kumm. & 2 & 5 & sl & - \\
\hline 84 & Hypholoma lateritium (Schaeff.) P. Kumm. & 1 & 1 & sl & - \\
\hline 85 & Infundibulicybe geotropa (Bull.) Harmaja & 1 & 1 & st & - \\
\hline 86 & Inocybe asterospora Quél. s. $l$. & 1 & 1 & $\mathrm{~m}$ & 3 \\
\hline 87 & Inocybe flocculosa Sacc. s. $l$. & 1 & 1 & $\mathrm{~m}$ & 3 \\
\hline 88 & Inocybe geophylla (Bull.) P. Kumm. & 1 & 3 & $\mathrm{~m}$ & 3 \\
\hline 89 & Inocybe rimosa (Bull.) P. Kumm. & 1 & 3 & $\mathrm{~m}$ & - \\
\hline 90 & Laccaria amethystina Cooke & 1 & 1 & $\mathrm{~m}$ & 3 \\
\hline
\end{tabular}




\begin{tabular}{|c|c|c|c|c|c|}
\hline Nr. & Species & $\mathrm{rA}$ & Lo & Ls & $\mathrm{P}$ \\
\hline 91 & Laccaria bicolor (Maire) P.D. Orton & 1 & 1 & $\mathrm{~m}$ & 3 \\
\hline 92 & Lacrymaria lacrymabunda (Bull.) Pat. & 4 & 7 & st & - \\
\hline 93 & Lactarius aurantiacus (Pers.) Gray & 1 & 2 & $\mathrm{~m}$ & - \\
\hline 94 & Lactarius blennius (Fr.) Fr. & 1 & 1 & $\mathrm{~m}$ & - \\
\hline 95 & Lactarius chrysorrheus Fr. & 1 & 2 & $\mathrm{~m}$ & - \\
\hline 96 & Lactarius circellatus Fr. & 1 & 1 & $\mathrm{~m}$ & - \\
\hline 97 & Lactarius decipiens Quél. & 1 & 1 & $\mathrm{~m}$ & - \\
\hline 98 & Lactarius deliciosus (L.) Gray & 1 & 1 & $\mathrm{~m}$ & 4 \\
\hline 99 & Lactarius deterrimus Gröger & 1 & 2 & $\mathrm{~m}$ & - \\
\hline 100 & Lactarius quietus (Fr.) Fr. & 3 & 7 & $\mathrm{~m}$ & - \\
\hline 101 & Lactarius sanguifluus (Paulet) Fr. & 2 & 1 & $\mathrm{~m}$ & - \\
\hline 102 & Lactarius torminosus (Schaeff.) Gray & 1 & 1 & $\mathrm{~m}$ & 4 \\
\hline 103 & Lactarius turpis (Weinm.) Fr. & 1 & 2 & $\mathrm{~m}$ & 3 \\
\hline 104 & Leccinum pseudoscabrum (Kallenb.) Šutara & 1 & 1 & $\mathrm{~m}$ & 4 \\
\hline 105 & Lentinus tigrinus (Bull.) Fr. & 1 & 1 & sl & - \\
\hline 106 & Lepiota cristata $\mathrm{P}$. Kumm. & 2 & 6 & st & - \\
\hline 107 & Lepista inversa (Scop.) Pat. & 4 & 5 & st & - \\
\hline 108 & Lepista luscina (Fr.) Singer & 1 & 1 & st & - \\
\hline 109 & Lepista nuda (Bull.) Cooke & 2 & 5 & st & - \\
\hline 110 & Lepista saeva (Fr.) P. D. Orton & 1 & 2 & st & - \\
\hline 111 & Lepista sordida (Schumach.) Singer & 1 & 2 & st & - \\
\hline 112 & Leucoagaricus americanus (Peck) Vellinga & 1 & 1 & st & 2 \\
\hline 113 & Leucoagaricus leucothites (Vittad.) Wasser & 2 & 3 & st & - \\
\hline 114 & Lycoperdon perlatum Pers. & 1 & 1 & st & - \\
\hline 115 & Lycoperdon pratense Pers. & 1 & 1 & st & 2 \\
\hline 116 & Lyophyllum decastes (Fr.) Singer & 2 & 4 & st & - \\
\hline 117 & Macrolepiota mastoidea (Fr.) Singer & 1 & 1 & st & - \\
\hline 118 & Macrotyphula fistulosa (Holmsk.) R.H. Petersen & 1 & 1 & sl & 3 \\
\hline 119 & Marasmius oreades (Bolton) Fr. & 1 & 1 & $\mathrm{sc}$ & - \\
\hline 120 & Melanogaster variegatus (Vittad.) Tul. \& C. Tul. & 1 & 2 & $\mathrm{~m}$ & 3 \\
\hline 121 & Melanoleuca melaleuca (Pers.) Murrill & 1 & 1 & st & - \\
\hline 122 & Mycena galericulata (Scop.) Gray & 1 & 1 & st & - \\
\hline 123 & Mycena polygramma (Bull.) Gray & 1 & 1 & sl & - \\
\hline 124 & Mycena pura (Pers.) P. Kumm. & 3 & 7 & st & - \\
\hline 125 & Mycena rosea Gramberg & 1 & 2 & st & - \\
\hline 126 & Panellus stipticus (Bull.) P. Karst. & 1 & 1 & sl & - \\
\hline 127 & Paxillus involutus (Batsch) Fr. & 1 & 2 & $\mathrm{~m}$ & - \\
\hline 128 & Pholiota squarrosa (Vahl) P. Kumm. & 1 & 1 & sl & 3 \\
\hline 129 & Placodes betulinus (Bull.) Quél. & 1 & 2 & $\mathrm{p}$ & - \\
\hline 130 & Pleurotus ostreatus (Jacq.) P. Kumm. & 1 & 2 & $\mathrm{p}$ & - \\
\hline 131 & Pluteus atromarginatus (Konrad) Kühner & 1 & 1 & sl & 4 \\
\hline 132 & Pluteus cervinus (Schaeff.) P. Kumm. & 3 & 8 & sl & - \\
\hline 133 & Pluteus ephebeus (Fr.) Gillet & 1 & 1 & sl & 4 \\
\hline 134 & Polyporus arcularius (Batsch) Fr. & 1 & 1 & sl & - \\
\hline 135 & Polyporus squamosus (Huds.) Fr. & 1 & 2 & $\mathrm{p}$ & - \\
\hline 136 & Polyporus tuberaster (Jacq. ex Pers.) Fr & 1 & 1 & sl & 3 \\
\hline 137 & Psathyrella artemisiae (Pass.) Konrad \& Maubl. s. $l$. & 1 & 1 & sl & 3 \\
\hline 138 & Psathyrella candolleana (Fr.) Maire & 1 & 1 & sl & - \\
\hline
\end{tabular}




\begin{tabular}{|c|c|c|c|c|c|}
\hline Nr. & Species & $\mathrm{rA}$ & Lo & Ls & $\mathrm{P}$ \\
\hline 139 & Psathyrella marcescibilis (Britzelm.) Singer & 3 & 8 & st & 3 \\
\hline 140 & Psathyrella multipedata (Peck) A. H. Sm. & 1 & 1 & sl & 3 \\
\hline 141 & Psathyrella piluliformis (Bull.) P. D. Orton & 1 & 2 & sl & - \\
\hline 142 & Ramaria stricta (Pers.) Quél. & 1 & 2 & sl & - \\
\hline 143 & Rhodocollybia butyracea (Bull.) Lennox & 3 & 6 & st & - \\
\hline 144 & Rhodocybe gemina (Paulet) Kuyper \& Noordel. & 1 & 2 & st & 3 \\
\hline 145 & Russula cyanoxantha (Schaeff.) Fr. & 1 & 2 & $\mathrm{~m}$ & - \\
\hline 146 & Russula delica Fr. & 1 & 1 & $\mathrm{~m}$ & - \\
\hline 147 & Russula emetica (Schaeff.) Pers. s. $l$. & 1 & 1 & $\mathrm{~m}$ & 3 \\
\hline 148 & Russula foetens Pers. & 2 & 4 & $\mathrm{~m}$ & - \\
\hline 149 & Russula lepida Fr. & 1 & 1 & $\mathrm{~m}$ & 3 \\
\hline 150 & Russula undulata Velen. & 1 & 2 & $\mathrm{~m}$ & 3 \\
\hline 151 & Schizophyllum commune Fr. & 4 & 12 & sl & - \\
\hline 152 & Scleroderma citrinum Pers. & 2 & 4 & $\mathrm{~m}$ & 4 \\
\hline 153 & Scleroderma verrucosum (Bull.) Pers. & 2 & 3 & $\mathrm{~m}$ & 4 \\
\hline 154 & Stereum hirsutum (Willd.) Pers. & 1 & 2 & sl & - \\
\hline 155 & Strobilurus stephanocystis (Kühner \& Romagn. ex Hora) Singer & 1 & 1 & $\mathrm{sc}$ & - \\
\hline 156 & Stropharia aeruginosa (Curtis) Quél. & 3 & 6 & st & - \\
\hline 157 & Stropharia coronilla (Bull. ex DC.) Quél. & 1 & 2 & st & - \\
\hline 158 & Stropharia rugosoannulata Farl. ex Murrill & 1 & 1 & st & 3 \\
\hline 159 & Suillus granulatus (L.) Roussel & 5 & 15 & $\mathrm{~m}$ & - \\
\hline 160 & Suillus grevillei (Klotzsch) Singer & 2 & 4 & $\mathrm{~m}$ & - \\
\hline 161 & Suillus viscidus (L.) Roussel & 2 & 6 & $\mathrm{~m}$ & 3 \\
\hline 162 & Tephrocybe rancida (Fr.) Donk & 1 & 1 & st & 3 \\
\hline 163 & Trametes versicolor (L.) Lloyd & 2 & 3 & sl & - \\
\hline 164 & Tricholoma batschii Gulden & 1 & 4 & $\mathrm{~m}$ & 3 \\
\hline 165 & Tricholoma scalpturatum (Fr.) Quél. & 2 & 2 & $\mathrm{~m}$ & 3 \\
\hline 166 & Tricholoma terreum (Schaeff.) P. Kumm. & 3 & 5 & $\mathrm{~m}$ & - \\
\hline 167 & Tubaria furfuracea (Pers.) Gillet & 1 & 2 & sl & - \\
\hline 168 & Volvopluteus gloiocephalus (DC.) Vizzini, Contu \& Justo & 1 & 3 & sl & - \\
\hline 169 & Xerocomus cisalpinus Simonini, H. Ladurner \& Peintner & 1 & 1 & $\mathrm{~m}$ & 4 \\
\hline 170 & Xerocomus porosporus (Imler ex Bon \& G. Moreno) Contu & 1 & 1 & $\mathrm{~m}$ & 4 \\
\hline 171 & Xerula radicata (Relhan) Dörfelt. & 4 & 10 & sl & - \\
\hline
\end{tabular}

